\title{
The 4.2 ka BP event in the Levant
}

\author{
David Kaniewski ${ }^{1,2,3}$, Nick Marriner ${ }^{4}$, Rachid Cheddadi ${ }^{5}$, Joël Guiot ${ }^{6}$, and Elise Van Campo ${ }^{1,2}$ \\ ${ }^{1}$ Université Paul Sabatier-Toulouse 3, EcoLab (Laboratoire d'Ecologie Fonctionnelle et Environnement), \\ Bâtiment 4R1, 118 Route de Narbonne, 31062 Toulouse cedex 9, France \\ ${ }^{2}$ CNRS, EcoLab (Laboratoire d'Ecologie Fonctionnelle et Environnement), 31062 Toulouse cedex 9, France \\ ${ }^{3}$ Institut Universitaire de France, Secteur Biologie-Médecine-Santé, 103 boulevard Saint Michel, 75005 Paris, France \\ ${ }^{4}$ CNRS, Laboratoire Chrono-Environnement UMR6249, MSHE Ledoux, USR 3124, Université de \\ Bourgogne-Franche-Comté, UFR ST, 16 Route de Gray, 25030 Besançon, France \\ ${ }^{5}$ Université Montpellier II, CNRS-UM2-IRD, ISEM, France \\ ${ }^{6}$ Aix-Marseille Université, CEREGE, CNRS, UM34, Europôle de l'Arbois BP80, 13545 Aix-en-Provence, France
}

Correspondence: David Kaniewski (david.kaniewski@univ-tlse3.fr)

Received: 4 July 2018 - Discussion started: 17 July 2018

Revised: 28 September 2018 - Accepted: 3 October 2018 - Published: 22 October 2018

\begin{abstract}
The $4.2 \mathrm{kaBP}$ event is defined as a phase of environmental stress characterized by severe and prolonged drought of global extent. The event is recorded from the North Atlantic through Europe to Asia and has led scientists to evoke a 300-year global mega-drought. For the Mediterranean and the Near East, this abrupt climate episode radically altered precipitation, with an estimated $30 \%-50 \%$ drop in rainfall in the eastern basin. While many studies have highlighted similar trends in the northern Mediterranean (from Spain to Turkey and the northern Levant), data from northern Africa and the central-southern Levant are more nuanced, suggesting a weaker imprint of this climate shift on the environment and/or different climate patterns. Here, we critically review environmental reconstructions for the Levant and show that, while the $4.2 \mathrm{ka} \mathrm{BP}$ event also corresponds to a drier period, a different climate pattern emerges in the central-southern Levant, with two arid phases framing a wetter period, suggesting a W-shaped event. This is particularly well expressed by records from the Dead Sea area.
\end{abstract}

\section{Introduction}

While severe climate changes have been recorded during the Holocene (e.g., Mayewski et al., 2004; Wanner et al., 2008; Magny et al., 2013; Solomina et al., 2015; Guiot and Kaniewski, 2015) with uncertain overall effects, one period of increasing aridity, termed the $4.2 \mathrm{ka} \mathrm{BP}$ event (e.g., Weiss,
2016, 2017), has fueled debates on the causal link between climate shifts and societal upheavals during the Bronze Age (e.g., Finné et al., 2011; Butzer, 2012; Clarke et al., 2016). The $4.2 \mathrm{kaBP}$ event, which lasted $\sim 300$ years (from 4200 to 3900 cal yr BP), is probably one of the Holocene's best studied climatic events (e.g., Weiss et al., 1993; Cullen et al., 2000; deMenocal, 2001; Weiss and Bradley, 2001; Staubwasser and Weiss, 2006; Weiss, 2017; Manning, 2018; and references therein), although its chronology may be much wider than traditionally reported, extending from 4500 to 3500 BP (Gasse, 2000; Booth et al., 2005). This phase of aridity, considered to be of global extent (Booth et al., 2005, 2006; Fisher et al., 2008; Baker et al., 2009; Wanner et al., 2011, 2015), is now used as a formal boundary to separate the Middle and Late Holocene (Late Holocene Meghalayan Age; Walker et al., 2012; Zanchetta et al., 2016; and letter from the International Union of Geological Sciences). According to Arz et al. (2006), most records show a gradual climate shift rather than a specific abrupt event. Drought cooccurs with widespread cooling in the North Atlantic from 4300 to $4000 \mathrm{BP}$, as attested in Iceland (lake Hvítárvatn and lake Haukadalsvatn; Geirsdóttir et al., 2013; Blair et al., 2015). The event is also characterized by two short spikes of negative-type North Atlantic oscillations (NAOs) at 4300 and $3950 \mathrm{BP}$ (Olsen et al., 2012). During this interval, the Atlantic subpolar and subtropical surface waters cooled by 1 to $2^{\circ} \mathrm{C}$ (Bond et al., 1997, 2001; Bianchi and McCave, 1999; deMenocal, 2001). 
Focusing on the $4.2 \mathrm{kaBP}$ event in the Mediterranean, a detailed vegetation-based model shows that a significant drop in precipitation began in the eastern basin at $\sim$ $4300 \mathrm{BP}$. These drier conditions lasted until $4000 \mathrm{BP}$ with peaks in drought during the period 4300-4200 BP (Guiot and Kaniewski, 2015). Based on these modeling data (and the selected datasets), the western Mediterranean does not appear to have been significantly affected by the precipitation anomaly. A climate model reported by Brayshaw et al. (2011) also suggests that the eastern Mediterranean was drier, while the whole Mediterranean exhibited an increase in precipitation for the period 6000-4000 BP. A bipolar east-west "climate seesaw" was proposed to explain these contrasting spatiotemporal trends during the last millennia, with the hydroclimatic schemes across the basin being mediated by a combination of different climate modes (Roberts et al., 2012). It has been argued that the $4.2 \mathrm{kaBP}$ event resulted from changes in the direction and intensity of the cyclonic North Atlantic westerlies, controlled by the NAO (e.g., Cullen et al., 2002; Kushnir and Stein, 2010; Lionello et al., 2013). These westerlies modulate moisture transport across the Mediterranean and western Asia (see full map in Weiss, 2017) and, in the Mediterranean, interact with the tropical (monsoonal) climatic system (e.g., Rohling et al., 2002; Lamy et al., 2006; Lionello et al., 2006; Magny et al., 2009). The "climate seesaw" model further suggests that precipitation regimes could not have solely been modulated by NAO forcing, but also by other patterns (e.g., polar Eurasia and the eastern Atlanticwestern Russia) that acted in synergy (see full details in Roberts et al., 2012). For instance, other climate regimes, such as shifts in the Intertropical Convergence Zone (ITCZ), may also have played roles in mediating climate in the southern Mediterranean. In the Mediterranean basin, the $4.2 \mathrm{ka} \mathrm{BP}$ event could thus be a combination of different forcing factors (depending on the location and on seasonality) acting in tandem (e.g., Di Rita et al., 2018). Even if such hypotheses (Brayshaw et al., 2011; Roberts et al., 2012; Guiot and Kaniewski, 2015) are based merely on modeling data, they are useful in trying to understand the geographic dimensions of climate change during this period and to identify the mechanisms driving this important event.

Here, we examine several records from the Levant to critically review the climate context of the $4.2 \mathrm{ka}$ BP event in the eastern Mediterranean (Fig. 1). Our review is based on the core area of the central-southern Levant comprising Israel, the West Bank, and Jordan, as well as on the northern Levant with Syria and Lebanon. Other regions have also been integrated into our analysis, including Egypt (Nile Delta) and the Red Sea. All data (biotic and abiotic) were $z$ score transformed to facilitate inter-site comparisons (see citations for the original curves). The curves were directly drawn using the original values (when the data were available in open access repositories) or extracted from the publications when the raw data were not available (using the software GraphClick). This comprehensive west-east/north-south re- view of the Mediterranean data places emphasis on different climate patterns and climatic modes.

\section{Chronology}

The comparison of multiple $4.2 \mathrm{ka} \mathrm{BP}$ records involves assumptions regarding the relative weight of such variables in shaping the final outcomes and also requires strong evidence regarding the sensitivity of each proxy to fully record the environmental parameters. Our review also underscores the importance of robust chronologies in examining the spatial dimensions of the $4.2 \mathrm{ka} \mathrm{BP}$ event and its driving mechanisms. The age model of some of the climate proxies is built on radiocarbon $\left({ }^{14} \mathrm{C}\right)$ chronologies, with sometimes broad chronological windows due to the $2 \sigma$ calibrations. Telford et al. (2004) have previously shown that any single value, not its intercept or any other calculation, adequately describes the complex shape of a ${ }^{14} \mathrm{C}$ probability density function and that the use of the full probability distribution is recommended. Because it is impossible to critically revaluate each sequence mentioned in this review, one must refer to the original papers for further information. To reduce the uncertainties resulting from the calibration of ${ }^{14} \mathrm{C}$ measurements, high-resolution chronological datasets (e.g., Sharifi et al., 2015; Cheng et al., 2015) here serve as anchor points for other sequences.

\section{A west-east gradient - northern Mediterranean}

While Mediterranean climate models (Brayshaw et al., 2011; Guiot and Kaniewski, 2015) suggest that the $4.2 \mathrm{ka} \mathrm{BP}$ event is best expressed in the eastern Mediterranean and western Asia, drought nonetheless seems to be recorded in both western and eastern areas. A short review of the paleoclimate data from Spain to Turkey puts these drier conditions in a wider perspective.

In Spain, drier environmental conditions were recorded at several locations such as the Doñana National Park (JiménezMoreno et al., 2015), Sierra de Gádor (Carrión et al., 2003), Borreguiles de la Virgen (Jiménez-Moreno and Anderson, 2012), and Lake Montcortès (Scussolini et al., 2011). Further east, in Italy, several sites such as Renella Cave (Fig. 2; Drysdale et al., 2006; Zanchetta et al., 2016), Corchia Cave (Fig. 2; Regattieri et al., 2014), and Lake Accesa (Magny et al., 2009; revised chronology in Zanchetta et al., 2018) clearly point to a drought event. In Croatia, a drier climate is attested at Lake Vrana (Island of Cres; Schmidt et al., 2000), Bokanjačko blato karst polje (Dalmatia; Ilijanić et al., 2018), and at Mala Špilja Cave (island of Mljet; Lončar et al., 2017). In the Balkan Peninsula, Lake Shkodra (Fig. 2; Albania, Montenegro; Zanchetta et al., 2012), Lake Prespa (Republics of Macedonia, Albania, and Greece; Wagner et al., 2010), Lake Ohrid (Republics of Macedonia and Albania; Wagner et al., 2010), and Lake Dojran (Fig. 2; Macedonia, Greece; 


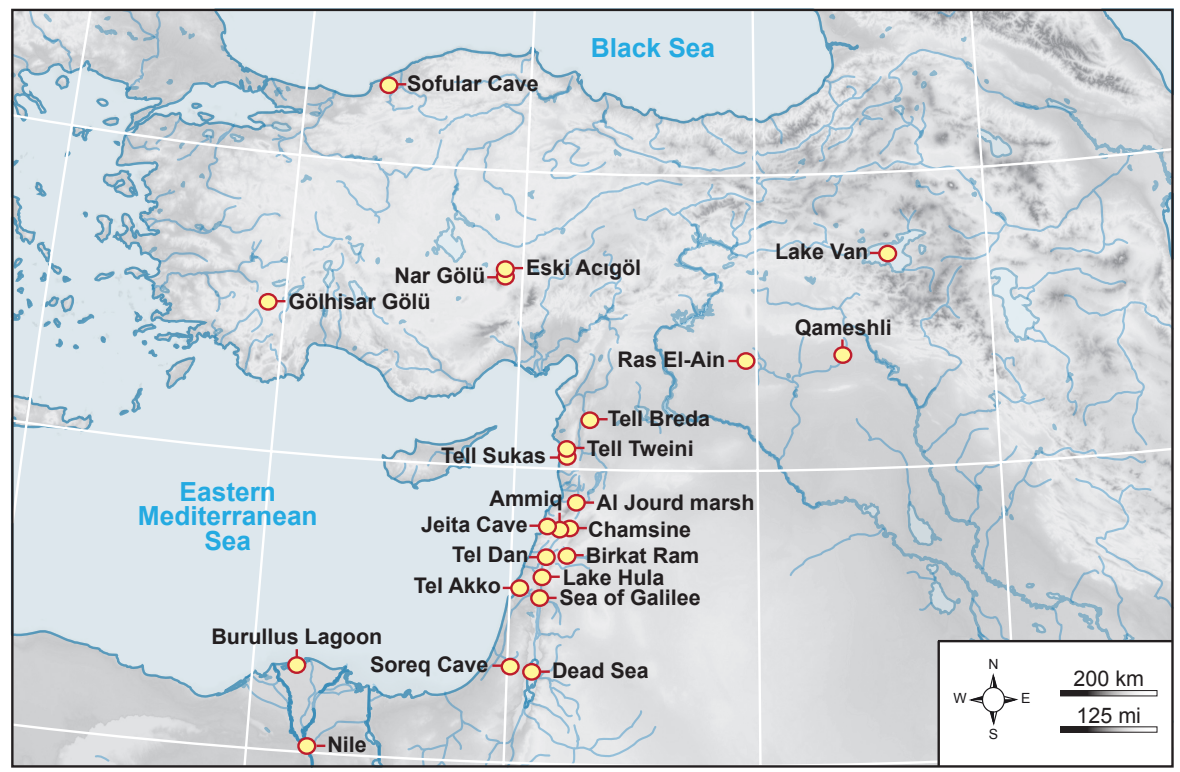

Figure 1. Geographical location of some of the main Levantine sites discussed in this study. Nearby sites in Turkey and Egypt are also displayed on the map (see the text for full references).

Francke et al., 2013; Thienemann et al., 2017; Rothacker et al., 2018) were also hit by drought, but of varying intensities. In Albania, a pollen-based model underscores a moderate decline in precipitation at Lake Maliq (Korçë; Bordon et al., 2009). In Greece, the Mavri Trypa Cave (Peloponnese; Finné et al., 2017) and the Omalos Polje karstic depression (Crete; Styllas et al., 2018) displayed a period of drier conditions centered on the $4.2 \mathrm{kaBP}$ event. In Turkey, the last "northern geographic step" before the Levant, drought is suggested at several locations. At Nar Gölü (Dean et al., 2015), Lake Van (Lemcke and Sturm, 1996; Wick et al., 2003), Gölhisar Gölü (Eastwood et al., 1999), and Eski Acıgöl (Roberts et al., 2008), drier conditions seem to prevail.

These data from the northern Mediterranean point to a drought episode broadly correlated with the chronological window of the $4.2 \mathrm{kaBP}$ event. This climate shift was recently framed by the Agnano-Mt. Spina ( $4400 \mathrm{BP})$ and the Avellino tephra layers $(\sim 3900 \mathrm{BP})$ in cores from the central Mediterranean (Zanchetta et al., 2018). As a consequence, the chronology of previous paleoenvironmental studies, including Lake Accesa, have been revised in line with this tephrostratigraphy (Zanchetta et al., 2018).

Knowledge gaps remain regarding the teleconnections and synergy between different climate patterns and their relative weight, according to the geographical location of the sites considered. The potential climate changes that may have impacted the northern Mediterranean during the $4.2 \mathrm{ka} \mathrm{BP}$ event have been extensively reviewed in the literature (e.g., Drysdale et al., 2006; Magny et al., 2009; Dean et al., 2015; Zanchetta et al., 2016; Di Rita et al., 2018) and will be discussed elsewhere in this special issue.

\section{A west-east gradient - southern Mediterranean}

Even if the 4.2 ka BP event is clearly delineated in the northern basin, the southern Mediterranean shows different trends due to the influence of Saharan climate. While similar dry conditions occurred concurrently in Morocco (Tigalmamine, Middle Atlas; Lambs et al., 1995; Cheddadi et al., 1998) and Algeria (Gueldaman GLD1 Cave; Ruan et al., 2016), the same arid conditions led to enhanced sediment delivery mediated by flash-flood activity (mainly due to poor vegetation cover) during the $4.2 \mathrm{ka} \mathrm{BP}$ event. Such extreme hydrological events are documented in fluvial stratigraphy from northern Africa (both in Morocco and Tunisia), especially during the period 4100-3700 BP (Faust et al., 2004; Benito et al., 2015). These hydrological events have also been identified in central Tunisia, a desert margin zone characterized by a transition from the subhumid Mediterranean to arid Saharan climate. Increased flood activity in river systems also occurred locally during the period 4100-3700 BP (Zielhofer and Faust, 2008). In the central Medjerda basin (northern Tunisia), enhanced fluvial dynamics started earlier, at $\sim 4700 \mathrm{BP}$, and lasted until 3700 BP (Faust et al., 2004).

Further east in Libya, the most dramatic environmental change in the area related to the onset of dry conditions took place earlier, at $\sim 5000$ years BP in Tadrart Acacus (Libyan Sahara; Cremaschi and Di Lernia, 1999). In the Jefara Plain, northwestern Libya, the "late Holocene arid climate period" started after 4860-4620 BP (Giraudi et al., 2013). These two distant Libyan areas are both dominated by Saharan climate, even though the Mediterranean is only $100 \mathrm{~km}$ from the Jefara Plain. This is consistent with data from Giraudi 


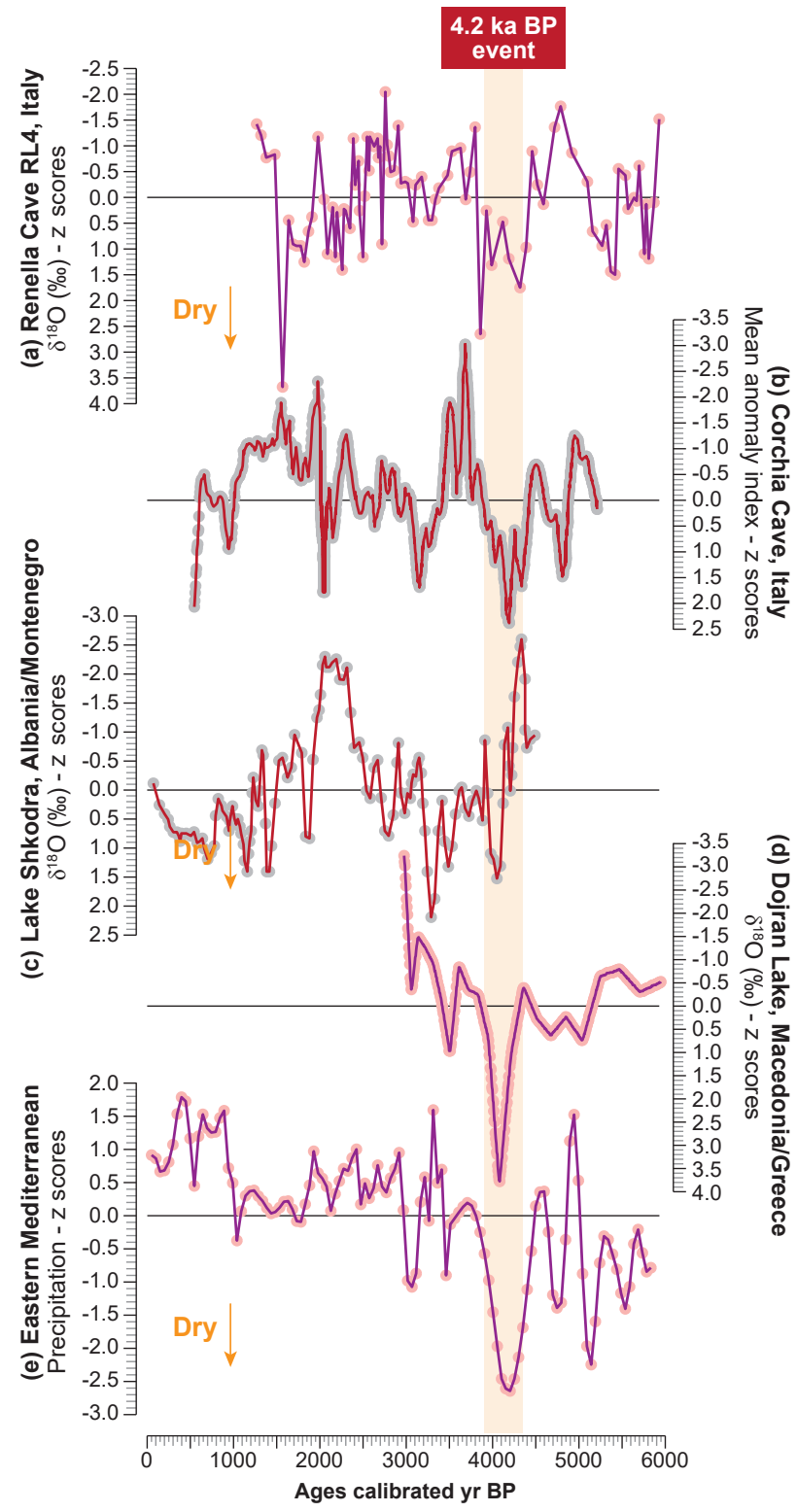

Figure 2. Paleoclimate series ( $z$ score transformed), with the type of climate proxy noted. The orange vertical band represents the $4.2 \mathrm{ka} \mathrm{BP}$ event. From top to bottom: Renella Cave (Italy; Drysdale et al., 2006; Zanchetta et al., 2016), Corchia Cave (Italy; Regattieri et al., 2014), Lake Shkodra (Albania and Montenegro; Zanchetta et al., 2012), Lake Dojran (Macedonia and Greece; Francke et al., 2013; Thienemann et al., 2017), and the eastern Mediterranean (Kaniewski et al., 2013).

et al. (2013), indicating that the Saharan climate extends to the coast of the Mediterranean Sea in Libya. Focusing on the Saharan climate and the African monsoon, a general deterioration of the terrestrial ecosystem is indicated at Lake Yoa, northern Chad, during the period $\sim 4800-4300$ BP. Since $4300 \mathrm{BP}$, widespread dust mobilization and the rapid transi- tion (4200-3900 BP) from a freshwater habitat to a salt lake are both recorded (Kröpelin et al., 2008).

In Egypt, the last "southern step" before the Levant, no major changes have been recorded at Lake Qarun (the deepest part of the Faiyum Depression; Baioumy et al., 2010), including the desiccation of Nile-fed Lake Faiyum occurring at $\sim 4200 \mathrm{BP}$ according to Hassan (1997). A recent study showed that Lake Qarun was low during the $4.2 \mathrm{ka} \mathrm{BP}$ event and that its level continued to fall until $3200 \mathrm{BP}$, in accordance with the conclusions of Hassan (1997). The lake was finally cut off from the Nile, with only rare inflows suggested by clayey silt depositions (Marks et al., 2018). The level of Lake Moeris (Faiyum Depression) dropped at $\sim 4400$ BP and rose again at $\sim 4000 \mathrm{BP}$ (Hassan, 1986). During the $4.2 \mathrm{ka}$ BP event, Nile base-flow conditions changed considerably with reduced inputs from the White Nile, a dominant contribution from the Blue Nile, and diminished precipitation (Stanley et al., 2003; Véron et al., 2013). The source of the Blue Nile, Lake Tana (Fig. 3), also manifests a drier phase, leading to a reduction in Nile flow during the same period (Marshall et al., 2011), in phase with other regional paleoclimate archives (Chalié and Gasse, 2002; Thompson et al., 2002). This drop in and/or failure of Nile floods was recorded by a decreased Nile sediment supply (Fig. 3; Marriner et al., 2012), while in the Burullus Lagoon (Nile Delta), reduced flow directly impacted marshland vegetation (Bernhardt et al., 2012). The Nile Delta region is not directly affected by monsoonal rainfall (this was also the case during the Holocene and at longer Pleistocene timescales; RossignolStrick, 1983; Arz et al., 2003; Felis et al., 2004; Grant et al., 2016). However, the Nile's hydrological regime is essentially mediated by river discharge upstream, i.e., by the East African monsoon regime, and only secondarily by in situ Mediterranean climatic conditions (Flaux et al., 2013; Macklin et al., 2015). In the northern Red Sea, located between the Mediterranean and African-SW Asian monsoonal rainfall regimes, the $4.2 \mathrm{kaBP}$ event has been identified by enhanced evaporation and increased salinity in the Shaban Deep basin (Fig. 3; Arz et al., 2006).

All of this evidence from the southern Mediterranean and northern Africa points to hydrological instability, both during and around the $4.2 \mathrm{ka} \mathrm{BP}$ event, due to multiple climate influences, mainly from Saharan Africa. In many North African cases, records show that climate changes at $\sim 4200 \mathrm{BP}$ are not characterized by abrupt events, but rather are part of either a long-term trend or multicentennial-scale variations, as suggested by Arz et al. (2006) for the Red Sea. Focusing on Nile flow, variations seem mainly to result from a shift in the dynamics of the ITCZ, which migrates latitudinally in response to both orbitally controlled climatic patterns (see Gasse, 2000; Ducassou et al., 2008; Kröpelin et al., 2008; Verschuren et al., 2009; Revel et al., 2010; Flaux et al., 2013; Marriner et al., 2013) and from changes in the El NiñoSouthern Oscillation (ENSO; see Moy et al., 2002; Leduc et al., 2009; Wolff et al., 2011), an important driver of decadal 


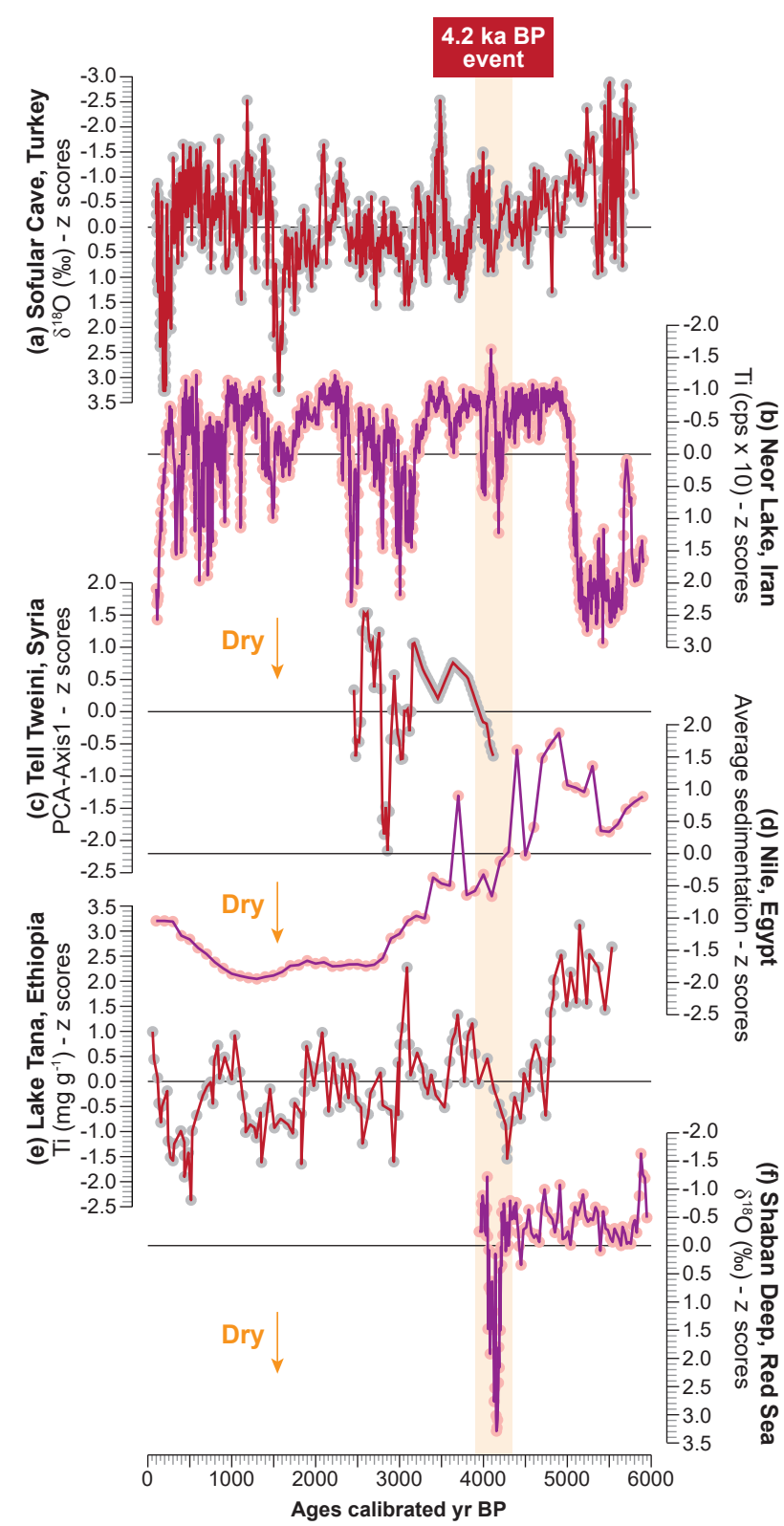

Figure 3. Paleoclimate series ( $z$ score transformed), with the type of climate proxy noted. The orange vertical band represents the 4.2 ka BP event. From top to bottom: Sofular Cave (Turkey; Göktürk et al., 2011), Neor Lake (Iran; Sharifi et al., 2015), Tell Tweini (Syria; Kaniewski et al., 2008), the Nile (Egypt; Marriner et al., 2012), Lake Tana (Marshall et al., 2011), and the Shaban Deep (Red Sea; Arz et al., 2006).

variations in precipitation over large parts of Africa (Indeje et al., 2000; Nicholson and Selato, 2000). The period encompassing the $4.2 \mathrm{kaBP}$ event is consistent with a decrease in ENSO-like frequency and a southern shift in the mean summer position of the ITCZ (Mayewski et al., 2004; Marshall et al., 2011) that may have reduced the interactions between
ENSO-like frequency and the Ethiopian monsoon (Moy et al., 2002; Marriner et al., 2012).

\section{The 4.2 ka BP event in the northern Levant}

Environmental data from the northern Levant derive from several locations in Syria and Lebanon, spatially distributed from the coastal strip to the dry inland areas.

\subsection{Syria}

The northern coastal lowlands of Syria, where Tell Tweini (Fig. 3) and Tell Sukas are located, are separated from the Ghab Depression to the east by the Jabal an Nuşayriyah, a $140 \mathrm{~km}$ long north-south mountain range 40 to $50 \mathrm{~km}$ wide with peaks culminating at $\sim 1200 \mathrm{~m}$ above sea level. At Tell Tweini (Jableh), the pollen-based environmental reconstruction (TW-1 core) shows that drier conditions prevailed during the $4.2 \mathrm{kaBP}$ event with weaker annual inputs of freshwater and ecological shifts induced by lower winter precipitation. The drier conditions ended at $\sim 3950 \mathrm{BP}$ (Fig. 3; Kaniewski et al., 2008). At Tell Sukas, $\sim 10 \mathrm{~km}$ south of Tell Tweini, an increase in dryness during the $4.2 \mathrm{ka} \mathrm{BP}$ event only coincides with a decline in olive exploitation, implying milder conditions (Sorrel et al., 2016). Olive abundances remain fairly high at Tell Tweini during the event, although the Olea pollen type originated from the wild variety (oleasters; Kaniewski et al., 2009), a tree species extremely resistant to drought that can survive in arid habitats (Lo Gullo and Salleo, 1988) and that cannot unequivocally be used as a proxy for "olive exploitation" (Kaniewski et al., 2009). In the Ghab Valley (e.g., van Zeist and Woldring, 1980; Yasuda et al., 2000), no reliable conclusions on climate shifts can be reported due to a floating chronology (e.g., Meadows, 2005). In continental Syria at Qameshli (near the TurkishIraqi border), modeled precipitation estimates (not based on paleoclimate proxy data) evoke a potential regional crisis in the rainfall regime beginning at around $4200 \mathrm{BP}$ (Bryson and Bryson, 1997; Fiorentino et al., 2008), echoing Lake Neor (flank of the Talesh-Alborz Mountains, Iran), where a major dust event resulting from drier conditions is clearly depicted (Fig. 3; Sharifi et al., 2015). The Qameshli climate model was used to calculate a potential decline in precipitation at Tell Breda (near Ebla) and Ras El-Ain. The two sites show similar trends to Qameshli, with a major dry event at $4200 \mathrm{BP}$ (Fiorentino et al., 2008). These "time series" (Bryson and Bryson, 1997; Fiorentino et al., 2008) are somewhat questionable as they derive solely from the macrophysical climate model developed by Bryson (1992; corrected by Fiorentino et al., 2008). More datasets are therefore needed to test the veracity of the Forientino et al. conclusions. Taking into account the outcomes of these published models, the data from Syria suggest that while the coastal area (Tell Sukas and Tell Tweini) was less affected by aridity, drought was potentially widespread inland during the $4.2 \mathrm{ka} \mathrm{BP}$ event from the south 
of Aleppo to the Turkish-Iraqi border. Unfortunately, no paleoenvironmental data are available for Tell Leilan despite its importance in narratives on the $4.2 \mathrm{ka} \mathrm{BP}$ event (e.g., Weiss et al., 1993; Weiss, 2016, 2017).

\subsection{Lebanon}

In Lebanon, the main paleoclimatic data in support of the 4.2 ka BP event derive from Jeita Cave (Fig. 4) and Al Jourd marsh (Fig. 4). Jeita Cave is located on the western flank of central Mount Lebanon. While the JeG-stm-1 stalagmite record $\left(\delta^{18} \mathrm{O}\right.$ and $\left.\delta^{13} \mathrm{C}\right)$ does not show compelling evidence for a rapid climate shift around $4200 \mathrm{BP}$ (Verheyden et al., 2008), new records (termed $\mathrm{J} 1-\mathrm{J} 3$; also based on $\delta^{18} \mathrm{O}$ and $\delta^{13} \mathrm{C}$ ) reveal that the $4.2 \mathrm{ka} \mathrm{BP}$ event is well defined, with a pronounced phase of climate change from 4300 to $3950 \mathrm{BP}$ (Fig. 4; Cheng et al., 2015). According to Verheyden et al. (2008), due to the low time resolution of this part of the JeG-stm-1 stalagmite (one sample every 180 years), the short-lived $4.2 \mathrm{ka} \mathrm{BP}$ event may have been missed. Further north at Sofular Cave (Turkey; Fig. 3), while the stalagmite So-1 is not affected by this low temporal resolution, no consistent and convincing signature for the $4.2 \mathrm{ka} \mathrm{BP}$ event was recorded (Göktürk et al., 2011), echoing the JeG-stm-1 stalagmite record. The absence of a $4.2 \mathrm{ka} \mathrm{BP}$ signal at Sofular Cave may result from the orography of the Black Sea and high precipitation that does not reflect the surrounding Mediterranean westerlies. The climate reconstruction from Al Jourd marsh, based on environmental data from the Al Jourd reserve ( $\sim 70 \mathrm{~km}$ northeast of Jeita Cave), shows the same trends as the J1-J3 cores (Cheddadi and Khater, 2016). The reconstructed precipitation results display a drier phase starting at $\sim 4220 \mathrm{BP}$ and lasting until $~ 3900 \mathrm{BP}$. At Ammiq (the Bekaa Valley), a strong decline in precipitation is recorded from $\sim 4700$ to $\sim 3850 \mathrm{BP}$, while at ChamsineAnjar (Bekaa Valley), the dry phase is centered on $4400 \mathrm{BP}$ before a gradual return to wet conditions that peak at $\sim$ 3930 BP (Cheddadi and Khater, 2016). The chronological discrepancies arising from Ammiq and Chamsine may potentially be the result of recalculated age models somewhat different from the original studies (Hajar et al., 2008, 2010). The age-depth models for the two records (Cheddadi and Khater, 2016) were modified and adjusted according to the marine chronostratigraphy proposed by Rossignol-Strick (1995).

Data from Lebanon suggest that a drier period centered on the 4.2 ka BP event was recorded (Cheng et al., 2015; Cheddadi and Khater, 2016). Sites in the Bekaa Valley (Ammiq, Chamsine) indicate that the drier phase started earlier, between 4700 and $4400 \mathrm{BP}$, but these sequences are built upon revised age models. The original interpretations suggest either an imprint of the $4.2 \mathrm{ka} \mathrm{BP}$ event at $\sim 4000$ BP (Hajar et al., 2008) or strong human impacts on the environment (Hajar et al., 2010).

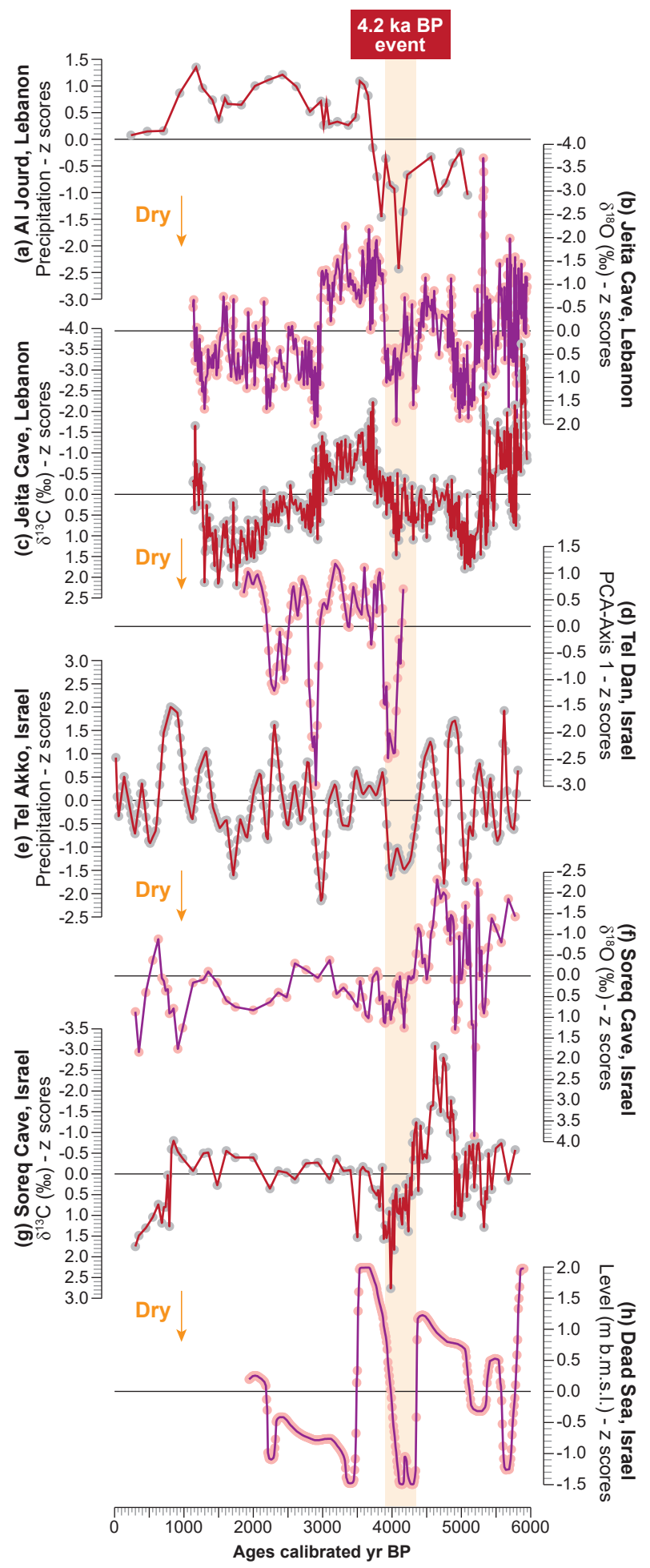

Figure 4. Paleoclimate series ( $z$ score transformed), with the type of climate proxy noted. The orange vertical band represents the 4.2 ka BP event. From top to bottom: Al Jourd (Lebanon; Cheddadi and Khater, 2016), Jeita Cave (Lebanon; Cheng et al., 2015), Tel Dan (Israel; Kaniewski et al., 2017), Tel Akko (Israel; Kaniewski et al., 2013), Soreq Cave (Israel; Bar-Matthews et al., 2003; BarMatthews and Ayalon, 2011), and the Dead Sea (Israel; Bookman (Ken-Tor) et al., 2004; Migowski et al., 2006; Kagan et al., 2015). 


\section{The $4.2 \mathrm{ka}$ BP event in the central-southern Levant}

In this section, the $4.2 \mathrm{ka} \mathrm{BP}$ event is presented from northern to southern Israel.

Located in the foothills of Mount Hermon in the Galilee Panhandle at the sources of the Jordan River, the site of Tel Dan (Israel) shows clear signatures of an arid event. A pollen-based environmental reconstruction depicts drier conditions characterized by a sharp drop in surface water between $\sim 4100$ and $\sim 3900 \mathrm{BP}$, with two main inflections at $\sim 4050$ and $\sim 3950$ BP (Fig. 4; Kaniewski et al., 2017). Approximately $10 \mathrm{~km}$ from Tel Dan, cores from the Birkat Ram crater lake (northern Golan Heights; Schwab et al., 2004), also located in the foothills of Mount Hermon, were used to reconstruct climate trends during the last 6000 years (Neuman et al., 2007a). The authors demonstrate that annual precipitation is comparatively uniform with no distinctive fluctuations during the study period (Neuman et al., 2007a). The pollen diagram from the Hula Nature Reserve (northwestern part of former Lake Hula, Israel) shows an expansion in Olea before 4110 BP (Baruch and Bottema, 1999; Van Zeist et al., 2009) but, because no distinction can be made between the wild or cultivated variety, this would suggest either (i) the expansion of olive orchards or (ii) drier conditions that favored drought-resistant trees, especially during a period characterized by decreasing cereals (see diagram in Van Zeist et al., 2009). A pollen-based environmental reconstruction from the Sea of Galilee (Lake Kinneret, Israel; e.g., Baruch, 1986; Miebach et al., 2017) shows two decreases in the oakpollen curve, interpreted as drier climate conditions at 4300 and $3950 \mathrm{BP}$ (Langgut et al., 2013), which may fit within the broader framework of the $4.2 \mathrm{ka} \mathrm{BP}$ event. In the same core, a decrease in tree-pollen scores was recorded around $4000 \mathrm{BP}$. According to the authors, it is unclear whether this environmental signal is related to the $4.2 \mathrm{kaBP}$ event (Schiebel and Litt, 2018).

Along the coast at Tel Akko (Acre, Israel), a pollen-based climate reconstruction shows negative precipitation anomalies centered on the period $\sim 4200-4000 \mathrm{BP}$, corresponding to an approximate $12 \%$ decrease in annual precipitation (Fig. 4; Kaniewski et al., 2013, 2014). At Soreq Cave (Judaean Mountains, Israel), rainfall was $\sim 30 \%$ lower for the period 4200-4050 BP (Fig. 4; Bar-Matthews et al., 1997, 1999, 2003; Bar-Matthews and Ayalon, 2011). While it has been noted that oxygen isotope ratios in speleothems cannot be used as a simple rainfall indicator (Frumkin et al., 1999; Kolodny et al., 2005; Litt et al., 2012), a similar value was suggested for the eastern Mediterranean with a decrease in annual precipitation of $\sim 30 \%$ (Fig. 2; Kaniewski et al., 2013).
Focusing on the Dead Sea (Israel, Jordan, and the West Bank), a lake-level reconstruction points to two sea-level drops at $\sim 4400$ and $\sim 4100 \mathrm{BP}$, separated by a short rise at $\sim$ 4200-4150 BP (Fig. 4; e.g., Bookman (Ken-Tor) et al., 2004; Migowski et al., 2006; Kagan et al., 2015). A similar short wet phase is recorded at Tel Akko at $\sim 4100 \mathrm{BP}$ (Kaniewski et al., 2013) and $\sim 4000 \mathrm{BP}$ at Tel Dan (Kaniewski et al., 2017), suggesting that minor chronological discrepancies can result from radiocarbon dating. The pollen-based environmental reconstruction from Ze'elim Gully (Dead Sea) echoes the Dead Sea level scores and suggests that drier climate conditions prevailed at $\sim 4300 \mathrm{BP}$ and $\sim 3950 \mathrm{BP}$, engendering an expansion of olive horticulture during the period $\sim 4150$ 3950 BP, which implies milder conditions (Neuman et al., 2007a; Langgut et al., 2014, 2016). Pollen data from a core drilled on the Ein Gedi shore (Dead Sea) were also used to reconstruct temporal variations in rainfall (Litt et al., 2012). While the $4.2 \mathrm{ka} \mathrm{BP}$ event corresponds to a relatively wet and cool period, two slightly drier phases were also recorded at $\sim 4400-4300 \mathrm{BP}$ and $\sim 3900 \mathrm{BP}$ (Litt et al., 2012). Even if some issues persist, the chronology of the Dead Sea (Ze'elim and Ein Feshkha sections) was strongly improved by Kagan et al. $(2010,2011)$, who produced Bayesian age-depth deposition models using the OxCal $P$-sequence model. The refined chronology of the Ze'elim Gully sequence and the Dead Sea are described in detail in Kagan et al. (2015).

The core DS 7-1 SC (Dead Sea; Heim et al., 1997), the core from Ein Feshkha (Dead Sea; Neuman et al., 2007b), and the marine cores off the Israeli coast (Schilman et al., 2001) were not included in our analysis because they do not cover the period under consideration.

Data from the southern Levant are complex compared to those from the northern Mediterranean. While the sites suggest that drier conditions were recorded during the $4.2 \mathrm{ka} \mathrm{BP}$ event from the Mediterranean coast to the Dead Sea, they nonetheless show that drought must be integrated into a broader chronological framework disrupted by a short wetter period. This W-shaped event is attested at several sites, suggesting that the W shape is not "noise" but a regional phenomenon spanning the central-southern Levant. A W-shaped event is clearly highlighted in the Dead Sea records (Litt et al., 2012; Langgut et al., 2014, 2016; Kagan et al., 2015; see Fig. 4) as well as at Soreq Cave $\left(\delta^{18} \mathrm{O}\right.$, Fig. 4; BarMatthews et al., 2003; Bar-Matthews and Ayalon, 2011) and is more or less attested in the Sea of Galilee (Langgut et al., 2013; Schiebel and Litt, 2018), at Tel Dan, and Tel Akko (Kaniewski et al., 2013, 2017). This W-shaped event may be a local expression of the North Atlantic Bond event 3 (Bond et al., 1997) because it has already been demonstrated that drier-wetter phases in the eastern Mediterranean were associated with cooling-warming periods in the North Atlantic during the past $55 \mathrm{kyr}$ (Bartov et al., 2003). 


\section{Climatic hypotheses to explain the $4.2 \mathrm{ka}$ BP event in the Levant}

\subsection{North Atlantic}

Kushnir and Stein (2010) have clearly noted that variability in southern Levant precipitation is closely linked with a seesaw pressure gradient between the eastern North Atlantic and Eurasia. Furthermore, they also evoke the apparent link between Atlantic multidecadal variability (Atlantic multidecadal sea surface temperature (SST) variability) and atmospheric circulation (see Kushnir, 1994; Ziv et al. 2006; Kushnir and Stein, 2010). Slowly paced Holocene variability is generally modulated by a colder than normal North Atlantic, resulting in higher than normal precipitation in the central Levant, while a warmer than normal North Atlantic leads to lower precipitation. This suggests that (i) the North Atlantic is a key pacemaker in driving the long-term hydroclimatic variability of the Levant during the Holocene, and (ii) there is a nonlinear response to global climatic events, such as the $4.2 \mathrm{ka} \mathrm{BP}$ event, consistent with pronounced cooling in eastern Mediterranean winter SSTs and cold events in northern latitudes (Kushnir and Stein, 2010). It appears that sudden Northern Hemisphere cold episodes contrast with milder and more slowly paced Holocene variability.

\subsection{A climate "seesaw" model}

A bipolar southeast-southwest "climate seesaw" in the Mediterranean is one of the climatic modes that explains the spatiotemporal variability of precipitation over the basin during the winter (Kutiel et al., 1996; Xoplaki et al., 2004), in connection with a positive or negative NAO. The dipole precipitation pattern results from both local cyclogenesis and southward shifts of storm tracks from western Europe towards the Mediterranean (and vice versa). Drier conditions in the eastern Mediterranean mainly derive from high-pressure systems over Greenland and Iceland and relatively low pressure over southwestern Europe (Roberts et al., 2012), pointing to a weakening of the zonal atmospheric circulation over Europe (Guiot and Kaniewski, 2015). According to Xoplaki et al. (2004), the outcomes of such a pattern over most of the Mediterranean region result in above normal precipitation, with peak values on the western seaboard and lower values in the southeastern part of the basin. This scheme fits with the Brayshaw et al. (2011) model that displays wetter conditions over large parts of the Mediterranean basin, while the eastern Mediterranean was drier. These conclusions are supported by Guiot and Kaniewski (2015). According to Roberts et al. (2012), this mode also prevailed during the Little Ice Age, with drier conditions over the eastern Mediterranean and wetter patterns over the western Mediterranean (with an opposite scheme during the Medieval Climate Anomaly).

\subsection{Cyprus lows}

While a dominant NAO forcing may explain western Mediterranean aridity, the eastern Mediterranean appears to be mostly mediated by other climatic modes. In particular, precipitation variability has not been uniform due to shifts in cyclone migration tracks (northern-southern). Rainfall in the Levant mostly originates from midlatitude cyclones (Cyprus lows) during their eastward passage over the eastern Mediterranean (Enzel et al., 2003; Zangvil et al., 2003; Saaroni et al., 2010). During wet years, more intense cyclones frequently migrate over the eastern Mediterranean (and vice versa), reflecting variations in the long-term mean low pressure, with positive pressure anomalies consistent with reduced cyclonic activity near the surface. Under this scenario, the most probable cause for drought events in the Levant is the fact that the $500 \mathrm{hPa}$ (upper-level anomalies) and sea-level pressure patterns were not conducive to cyclone migration over the eastern Mediterranean. Instead, their tracks were probably further to the north, potentially impacting western Turkey and Greece (Enzel et al., 2003).

\section{Conclusions}

At the scale of the Levant, a climate shift is clearly documented by sediment records during the chronological frame of the $4.2 \mathrm{ka} \mathrm{BP}$ event. Nonetheless, some locations show that other regional and/or local forcing agents may be involved, yielding different outcomes that must be more closely addressed in the future. Concerning the climate mechanism driving the $4.2 \mathrm{kaBP}$ event, we can assume that, despite the clear geographical dimensions of the $4.2 \mathrm{kaBP}$ event (Zanchetta et al., 2016; Di Rita et al., 2018), the patterns responsible for the event are not yet fully understood. This also raises a key question: how did societies adapt to this 300-year (or longer) drought? This knowledge gap is still widely debated and must be addressed using high-resolution local records in proximity to archeological sites to fully understand the resilience and adaptive strategies of the Levant's diverse peoples and polities.

Data availability. Data from this paper are available upon request to the corresponding author.

Supplement. The supplement related to this article is available online at: https://doi.org/10.5194/cp-14-1529-2018-supplement.

Author contributions. DK, NM, RC, JG, and EVC conceived the review and wrote the paper.

Competing interests. The authors declare that they have no conflict of interest. 
Special issue statement. This article is part of the special issue "The $4.2 \mathrm{ka}$ BP climatic event". It is a result of "The $4.2 \mathrm{ka} \mathrm{BP}$ Event: An International Workshop", Pisa, Italy, 10-12 January 2018.

Acknowledgements. Support was provided by the Institut Universitaire de France CLIMSORIENT program. This work is a contribution to Labex OT-Med (no. ANR-11-LABX-0061) and has received funding from the Excellence Initiative of Aix-Marseille University - A*MIDEX, a French "Investissements d'Avenir" project.

Edited by: Giovanni Zanchetta

Reviewed by: two anonymous referees

\section{References}

Arz, H. W., Lamy, F., Pätzold, P., Müller, P. J., and Prins, M.: Mediterranean moisture source for early-Holocene humid period in the Red Sea, Science, 300, 118-121, 2003.

Arz, H. W., Lamy, F., and Pätzold, J.: A pronounced dry event recorded around $4.2 \mathrm{ka}$ in brine sediments from the northern Red Sea, Quaternary Res., 66, 432-441, 2006.

Baioumy, H. M., Kayanne, H., and Tada, R.: Reconstruction of lakelevel and climate changes in Lake Qarun, Egypt, during the last 7000 years, J. Great Lakes Res., 36, 318-327, 2010.

Baker, P., Fritz, S., Burns, S., Ekdahl, E., and Rigsby, C.: The nature and origin of decadal to millennial scale climate variability in the southern tropics of South America: the Holocene record of Lago Umayo, Peru, in: Past climate variability in South America and surrounding regions: from the last glacial maximum to the Holocene, Developments in Paleoenvironmental Research 14, edited by: Vimeux, F., Sylvestre, F., and Khodri, M., SpringerVerlag, 301-322, 2009.

Bar-Matthews, M., Ayalon, A., and Kaufman, A.: Late Quaternary paleoclimate in the Eastern Mediterranean region from stable isotope analysis of speleothems at Soreq Cave, Israel, Quaternary Res., 47, 155-168, 1997.

Bar-Matthews, M., Ayalon, A., Kaufman, A., and Wasserburg, G. J.: The Eastern Mediterranean palaeoclimate as a reflection of regional events: Soreq Cave, Israel, Earth Planet. Sc. Lett., 166, 85-95, 1999.

Bar-Matthews, M., Ayalon, A., Gilmour, M., Matthews, A., and Hawkesworth, C. J.: Sea-land oxygen isotopic relationship from planktonic foraminifera and speleothems in the Eastern Mediterranean region and their implication for paleorainfall during interglacial intervals, Geochim. Cosmochim. Ac., 67, 3181-3199, 2003

Bar-Matthews, M. and Ayalon, A.: Mid-Holocene climate variations revealed by high-resolution speleothem records from Soreq Cave, Israel and their correlation with cultural changes, Holocene, 21, 163-171, 2011.

Bartov, Y., Goldstien, S. L., Stein, M., and Enzel, Y.: Catastrophic arid events in the East Mediterranean linked with the North Atlantic Heinrich events, Geology, 31, 439-442, 2003.

Baruch, U.: The late Holocene vegetational history of Lake Kinneret (sea of Galilee), Israel, Paléorient, 12, 37-47, 1986.
Baruch, U. and Bottema, S.: A new pollen diagram from Lake Hula: vegetational, climatic and anthropogenic implications, in: Ancient lakes: their cultural and biological diversity, edited by: Kawanabe, H., Coulter, G. W., and Roosevelt, A. C., Kenobi Productions, Ghent, 75-86, 1999.

Benito, G., Macklin, M. G., Zielhofer, C., Jones, A. F., and Machado, M. J.: Holocene flooding and climate change in the Mediterranean, Catena, 130, 13-33, 2015.

Bernhardt, C., Horton, B. P., and Stanley, J. D.: Nile Delta vegetation response to Holocene climate variability, Geology, 40, 615618, 2012.

Bianchi, G. G. and McCave, I. N.: Holocene periodicity in North Atlantic climate and deep-ocean flow south of Iceland, Nature, 397, 515-517, 1999.

Blair, C. L., Geirsdóttir, Á., and Miller, G. H.: A high-resolution multi-proxy lake record of Holocene environmental change in southern Iceland, J. Quaternary Sci., 30, 281-292, 2015.

Bond, G., Showers, W., Cheseby, M., Lotti, R., Almasi, P., deMenocal, P., Priore, P., Cullen, H., Hadjas, I., and Bonani, G.: A pervasive millennial-scale cycle in North Atlantic Holocene and glacial climates, Science, 278, 1257-1266, 1997.

Bond, G., Kromer, B., Beer, J., Muscheler, R., Evans, M.N., Showers, W., Hoffmann, S., Lotti-Bond, R., Hajdas, I., and Bonani, G.: Persistent Solar Influence on North Atlantic Climate during the Holocene, Science, 294, 3130-2136, 2001.

Bookman (Ken-Tor), R., Enzel, Y., Agnon, A., and Stein, M.: Late Holocene lake levels of the Dead Sea, Geol. Soc. Am. Bull., 116, 555-571, 2004.

Booth, R. K., Jackson, S. T., Forman, S. L., Kutzbach, J. E., Bettis, E. A., Kreig, J., and Wright, D. K.: A severe centennial-scale drought in mid-continental North America 4200 years ago and apparent global linkages, Holocene 15, 321-328, 2005.

Booth, R., Jackson, S., Forman, S., Kutzbach, J., Bettis, E., Kreig, J., and Wright D.: A severe centennial-scale drought in midcontinental North America 4200 years ago and apparent global linkages, Holocene 15, 321-328, 2006.

Bordon, A., Peyron, O., Lézine, A. M., Brewer, S., and Fouache, E.: Pollen-inferred Late-Glacial and Holocene climate in southern Balkans (Lake Maliq), Quatern. Int., 200, 19-30, 2009.

Brayshaw, D. J., Rambeau, C. M. C., and Smith, S. J.: Changes in Mediterranean climate during the Holocene: Insights from global and regional climate modelling, Holocene, 21, 15-31, 2011.

Bryson, R. A.: A macrophysical model of the Holocene intertropical convergence and jetstream position and rainfall for the Saharan region, Meteorol. Atmos. Phys., 47, 247-258, 1992.

Bryson, R. A. and Bryson, R. U.: High resolution simulations of regional Holocene climate: North Africa and the Near East, in: Third millennium B.C. climate change and old world collapse, NATO ASI Series, vol. I 49, edited by: Dalfes, H. N., Kukla, G., and Weiss, H., Springer-Verlag, Berlin Heidelberg, 565-593, 1997.

Butzer, K. W.: Collapse, environment, and society, P. Natl. Acad. Sci. USA, 109, 3632-3639, 2012.

Carrión, J. S., Sánchez-Gómez, P., Mota, J. F., Yll, E. I., and Chaín, C.: Fire and grazing are contingent on the Holocene vegetation dynamics of Sierra de Gádor, southern Spain, Holocene, 13, 839849, 2003.

Chalié, F. and Gasse, F.: Late-GlacialeHolocene diatom record of water chemistry and lake-level change from the tropical East 
African Rift Lake Abiyata (Ethiopa), Palaeogeogr. Palaeocl., 187, 259-283, 2002.

Cheddadi, R. and Khater, C.: Climate change since the last glacial period in Lebanon and the persistence of Mediterranean species, Quaternary Sci. Rev., 150, 146-157, 2016.

Cheddadi, R., Lamb, H. F., Guiot, J., and van der Kaars, S.: Holocene climatic change in Morocco: a quantitative reconstruction from pollen data, Clim. Dynam., 14, 883-890, 1998.

Cheng, H., Sinha, A., Verheyden, S., Nader, F. H., Li, X. L., Zhang, P. Z., Yin, J. J., Yi, L., Peng, Y. B., Rao, Z. G., Ning, Y. F., and Edwards, R. L.: The climate variability in northern Levant over the past 20000 years, Geophys. Res. Lett., 42, 8641-8650, 2015.

Clarke, J., Brooks, N., Banning, E. B., Bar-Matthews, M., Campbell, S., Clare, L., Cremaschi, M., di Lernia, S., Drake, N., Gallinaro, M., and Manning, S.: Climatic changes and social transformations in the Near East and North Africa during the "long" 4th millennium BC: A comparative study of environmental and archaeological evidence, Quaternary Sci. Rev. 136, 96-121, 2016.

Cremaschi, M. and Di Lernia, S.: Holocene Climatic Changes and Cultural Dynamics in the Libyan Sahara, Afr. Archaeol. Rev., 16, 211-238, 1999.

Cullen, H. M., deMenocal, P. B., Hemming, S., Brown, F., Guilderson, T., and Sirocko, F.: Climate change and the collapse of the Akkadian Empire: evidence from the deep sea, Geology, 28, 379-382, 2000.

Cullen, H. M., Kaplan, A., Arkin, P. A., and deMenocal, P. B.: Impact of the North Atlantic Oscillation on Middle Eastern climate and streamflow, Climatic Change, 55, 315-338, 2002.

Dean, J. R., Jones, M. D., Leng, M. J., Noble, S. R., Metcalfe, S. E., Sloane, H. J., Sahy, D., Eastwood, W. J., and Roberts, N.: Eastern Mediterranean hydroclimate over the late glacial and Holocene, reconstructed from the sediments of Nar lake, central Turkey, using stable isotopes and carbonate mineralogy, Quaternary Sci. Rev., 124, 162-174, 2015.

deMenocal, P. B.: Cultural responses to climatic change during the late Holocene, Science, 292, 667-673, 2001.

Di Rita, F., Fletcher, W. J., Aranbarri, J., Margaritelli, G., Lirer, F., and Magri, D.: Holocene forest dynamics in central and western Mediterranean: periodicity, spatio-temporal patterns and climate influence, Sci. Rep., 8, 8929, https://doi.org/10.1038/s41598018-27056-2, 2018.

Drysdale, R. N., Zanchetta, G., Hellstrom, J., Maas, R., Fallick, A. E., Pickett, M., Cartwright, I., and Piccini, L.: Late Holocene drought responsible for the collapse of Old World civilizations is recorded in an Italian cave flowstone, Geology, 34, 101-104, 2006.

Ducassou, E., Mulder, T., Migeon, S., Gonthier, E., Murat, A., Revel, M., Capotondi, L., Bernasconi, S. M., Mascle, J., and Zaragosi, S.: Nile floods recorded in deep Mediterranean sediments, Quaternary Res., 70, 382-391, 2008.

Eastwood, W. J., Roberts, N., Lamb, H. F., and Tibby, J. C.: Holocene environmental change in southwest Turkey: a palaeoecological record of lake and catchment-related changes, Quaternary Sci. Rev., 18, 671-695, 1999.

Enzel, Y., Bookman, R., Sharon, D., Gvirtzman, H., Dayan, U., Ziv, B., and Stein, M.: Late Holocene climates of the Near East deduced from Dead Sea level variations and modern regional winter rainfall, Quaternary Res., 60, 263-273, 2003.
Faust, D., Zielhofer, C., Baena Escudero, R., and Diaz del Olmo, F.: High-resolution fluvial record of late Holocene geomorphic change in northern Tunisia: climatic or human impact?, Quaternary Sci. Rev., 23, 1757-1775, 2004.

Felis, T., Lohmann, G., Kuhnert, H., Lorenz, S. J., Scholz, D., Pätzold, J., Al-Rousan, S. A., and Al-Moghrabi, S. M.: Increased seasonality in Middle East temperatures during the last interglacial period, Nature, 429, 164-168, 2004.

Finné, M., Holmgren, K., Sundqvist, H. S., Weiberg, E., and Lindblom, M.: Climate in the Eastern Mediterranean, and adjacent regions, during the past 6000 years - a review, J. Archaeol. Sci., 28, 3153-3173, 2011.

Finné, M., Holmgren, K., Shen, C. C., Hu, H. M., Boyd, M., and Stocker, S.: Late Bronze Age climate change and the destruction of the Mycenaean Palace of Nestor at Pylos, Plos One, 12, e0189447, doi.org/10.1371/journal.pone.0189447, 2017.

Fiorentino, G., Caracuta, V., Calcagnile, L., D’Elia, M., Matthiae, P., Mavelli, F., and Quarta, G.: Third millennium B.C. climate change in Syria highlighted by carbon stable isotope analysis of ${ }^{14} \mathrm{C}$-AMS dated plant remains from Ebla, Palaeogeogr. Palaeocl., 266, 51-58, 2008

Fisher, D., Osterberg, E., Dyke, A., Dahl-Jensen, D., Demuth, M., Zdanowicz, C., Bourgeois, J., Koerner, R., Mayewski, P., Wake, C., Kreutz, K., Steig, E., Zheng, J., Yalcin, K., Goto-Azuma, K., Luckman, B., and Rupper, S.: The Mt Logan Holocene late Wisconsinan isotope record: tropical Pacific-Yukon connections, Holocene, 18, 667-677, 2008.

Flaux, C., Claude, C., Marriner, N., and Morhange, C.: A 7500year strontium isotope record from the northwestern Nile delta (Maryut lagoon, Egypt), Quaternary Sci. Rev., 78, 22-33, 2013.

Francke, A., Wagner, B., Leng, M. J., and Rethemeyer, J.: A Late Glacial to Holocene record of environmental change from Lake Dojran (Macedonia, Greece), Clim. Past, 9, 481-498, https://doi.org/10.5194/cp-9-481-2013, 2013.

Frumkin, A., Ford, D. C., and Schwarcz, H. P.: Continental oxygen isotopic record of the last 170,000 years in Jerusalem, Quaternary Res., 51, 317-327, 1999.

Gasse, F.: Hydrological changes in the African tropics since the last glacial maximum, Quaternary Sci. Rev. 19, 189-212, 2000.

Geirsdóttir, Á., Miller, G. H., Larsen, D. J., and Ólafsdóttir, S.: Abrupt Holocene climate transitions in the northern North Atlantic region recorded by synchronized lacustrine records in Iceland, Quaternary Sci. Rev., 70, 48-62, 2013.

Giraudi, C., Mercuri, A. M., and Esu, D.: Holocene palaeoclimate in the northern Sahara margin (Jefara Plain, northwestern Libya), Holocene, 23, 339-352, 2013.

Göktürk, O. M., Fleitmann, D., Badertscher, S., Cheng, H., Edwards, R. L., Leuenberger, M., Fankhauser, A., Tüysüz, O., and Kramers, J.: Climate on the southern Black Sea coast during the Holocene: implications from the Sofular Cave record, Quaternary Sci. Rev., 30, 2433-2445, 2011.

Grant, K. M., Grimm, R., Mikolajewicz, U., Marino, G., Ziegler, M., and Rholing, E. J.: The timing of Mediterranean sapropel deposition relative to insolation, sea-level and African monsoon changes, Quaternary Sci. Rev., 140, 125-141, 2016.

Guiot, J. and Kaniewski, D.: The Mediterranean basin in a warmer and drier world: what can we learn from the past?, Front. Earth Sci., 3, 1-16, https://doi.org/10.3389/feart.2015.00028, 2015. 
Hajar, L., Khater, C., and Cheddadi, R.: Vegetation changes during the late Pleistocene and Holocene in Lebanon: a pollen record from the Bekaa valley, Holocene, 18, 1089-1099, 2008.

Hajar, L., Haïdar-Boustani, M., Khater, C., and Cheddadi, R.: Environmental changes in Lebanon during the Holocene: man vs. climate impacts, J. Arid Environ., 74, 746-755, 2010.

Hassan, F. A.: Holocene lakes and prehistoric settlements of the western Faiyum, Egypt, J. Archaeol. Sci., 13, 483-501, 1986.

Hassan, F. A.: The dynamics of a riverine civilization: a geoarchaeological perspective on the Nile Valley, Egypt, World Archaeol., 29, 51-74, 1997.

Heim, C., Nowaczyk, N. R., and Negendank, J. F. W.: Near East desertification: evidence from the Dead Sea, Naturwissenschaften, 84, 398-401, 1997.

Ilijanič, N., Miko, S., Hasan, O., and Bakrač, K.: Holocene environmental record from lake sediments in the Bokanjačko blato karst polje (Dalmatia, Croatia), Quatern. Int., in press, 2018.

Indeje, M., Semazzi, F. H. M., and Ogallo, L. J.: ENSO signals in East African rainfall seasons, Int. J. Climatol., 20, 19-46, 2000.

Jiménez-Moreno, G. and Anderson, R. S.: Holocene vegetation and climate change recorded in alpine bog sediments from the Borreguiles de la Virgen, Sierra Nevada, southern Spain, Quaternary Res., 77, 44-53, 2012.

Jiménez-Moreno, G., Rodríguez-Ramírez, A., Pérez-Asensio, J. N., Carrión, J. S., López-Sáez, J. A., Villarías-Robles, J. J., Celestino-Pérez, S., Cerrillo-Cuenca, E., León, Á., and Contreras, C.: Impact of late-Holocene aridification trend, climate variability and geodynamic control on the environment from a coastal area in SW Spain, Holocene, 25, 607-617, 2015.

Kagan, E., Stein, M., Agnon, A., and Neumann, F.: Intrabasin paleoearthquake and quiescence correlation of the Late Holocene Dead Sea, J. Geophys. Res., 116, B04311, https://doi.org/10.1029/2010JB007452, 2011.

Kagan, E. J., Stein, M., Agnon, A., and Bronk Ramsey, C.: Paleoearthquakes as anchor points in Bayesian radiocarbon deposition models: a case study from the Dead Sea, Radiocarbon, 54, 1018-1026, 2010.

Kagan, E. J., Langgut, D., Boaretto, E., Neumann, F. H., and Stein, M.: Dead Sea levels during the Bronze and Iron Ages, Radiocarbon 57, 237-252, 2015.

Kaniewski, D., Paulissen, E., Van Campo, E., Al-Maqdissi, M., Bretschneider, J., and Van Lerberghe, K.: Middle East coastal ecosystem response to middle-to-late Holocene abrupt climate changes, P. Natl. Acad. Sci. USA, 105, 13941-13946, 2008.

Kaniewski, D., Paulissen, E., Van Campo, E., Bakker, J., Van Lerberghe, K., and Waelkens, M.: Wild or cultivated Olea europaea L. in the Eastern Mediterranean during the middle-late Holocene? A pollen-numerical approach, Holocene, 19, 10391047, 2009.

Kaniewski, D., Van Campo, E., Morhange, C., Guiot, J., Zviely, D., Shaked, I., Otto, T., and Artzy, M.: Early urban impact on Mediterranean coastal environments, Sci. Rep., 3, 1-5, https://doi.org/10.1038/srep03540, 2013.

Kaniewski, D., Van Campo, E., Morhange, C., Guiot, J., Zviely, D., Le Burel, S., Otto, T., and Artzy, M.: Vulnerability of Mediterranean ecosystems to long-term changes along the coast of Israel, Plos One, 9, e102090, https://doi.org/10.1371/journal.pone.0102090, 2014.
Kaniewski, D., Marriner, N., Ilan, D., Morhange, C., Thareani, Y., and Van Campo, E.: Climate change and water management in the biblical city of Dan, Sci. Adv., 3, e1700954, https://doi.org/10.1126/sciadv.1700954, 2017.

Kolodny, Y., Stein, M., and Machlus, M.: Sea-rain-lake relation in the last glacial east Mediterranean revealed by $\mathrm{d}^{18} \mathrm{O}-\mathrm{d}^{13} \mathrm{C}$ in lake Lisan aragonites, Geochim. Cosmochim. Ac., 69, 40454060, 2005.

Kröpelin, S., Verschuren, D., Lézine, A. M., Eggermont, H., Cocquyt, C., Francus, P., Cazet, J. P., Fagot, M., Rumes, B., Russel, J. M., Darius, F., Conley, D. J., Schuster, M., von Suchodoletz, H., and Engstrom, D. R.: Climate-driven ecosystem succession in the Sahara: the past 6000 years, Science, 320, 765-768, 2008.

Kushnir, Y.: Interdecadal variations in North-Atlantic sea-surface temperature and associated atmospheric conditions, J. Climate, 7, 141-157, 1994.

Kushnir, Y. and Stein, M.: North Atlantic influence on 19th-20th century rainfall in the Dead Sea watershed, teleconnections with the Sahel, and implication for the Holocene climate fluctuations, Quaternary Sci. Rev., 29, 3843-3860, 2010.

Kutiel, H., Maheras, P., and Guika, S.: Circulation and extreme rainfall conditions in the eastern Mediterranean during the last century, Int. J. Climatol. 16, 73-92, 1996.

Lamb, H. F., Gasse, F., Benkaddour, A., El Hamouti, N., van der Kaars, S., Perkins, W. T., Pearce, N. J., and Roberts, C. N.: Relation between century-scale Holocene arid intervals in tropical and temperate zones, Nature, 373, 134-137, 1995.

Lamy, F., Arz, H. W., Bond, G. C., Bahr, A., and Pätzold, J.: Multicentennial-scale hydrological changes in the Black Sea and northern Red Sea during the Holocene and the Arctic/North Atlantic Oscillation, Paleoceanography, 21, 1-11, https://doi.org/10.1029/2005PA001184, 2006.

Langgut, D., Finkelstein, I., and Litt, T.: Climate and the Late Bronze collapse: new evidence from the Southern Levant, Tel Aviv, 40, 149-175, 2013.

Langgut, D., Neumann, F. H., Stein, M., Wagner, A., Kagan, E. J., Boaretto, E., and Finkelstein, I.: Dead Sea pollen record and history of human activity in the Judean Highlands (Israel) from the Intermediate Bronze into the Iron Ages ( 2500-500 BCE), Palynology, 38, 280-302, 2014.

Langgut, D., Adams, M. J., and Finkelstein, I.: Climate, settlement patterns and olive horticulture in the southern Levant during the Early Bronze and Intermediate Bronze Ages (c. 3600-1950 BC), Levant, 48, 117-134, 2016.

Leduc, G., Vidal, L., Cartapanis, O., and Bard, E., Modes of Eastern Equatorial Pacific thermocline variability: implications for ENSO dynamics over the last glacial period, Paleoceanography, 24, PA3202, https://doi.org/10.1029/2008PA001701, 2009.

Lemcke, G. and Sturm, M.: ${ }^{18} \mathrm{O}$ and trace elements measurements as proxy for reconstruction of climate change at Lake Van (Turkey), in: Third Millenium BC: climate change and old world collapse, NATO ASI Series I vol. 49, edited by: Dalfes, H. N., Kukla, G. H., and Weiss, H., Springer, Berlin, 653-678, 1996.

Lionello, P., Malanotte-Rizzoli, P., and Boscolo, R.: The Mediterranean climate: an overview of the main characteristics and issues, Elsevier, Netherlands, 2006.

Lionello, P., Malanotte-Rizzoli, P., and Boscolo, R.: Mediterranean climate variability: 4 (Developments in Earth and Environmental Sciences), Elsevier, Amsterdam, 2013. 
Litt, T., Ohlwein, C., Neumann, F. H., Hense, A., and Stein, M.: Holocene climate variability in the Levant from the Dead Sea pollen record, Quaternary Sci. Rev., 49, 95-105, 2012.

Lo Gullo, M. A. and Salleo, S.: Different strategies of drought resistance in three Mediterranean sclerophyllous trees growing in the same environmental conditions, New Phytol., 108, 267-76, 1988.

Lončar, N., Bar-Matthews, M., Ayalon, A., Surić, M., and Faivre, S.: Early and Mid-Holocene environmental conditions in the Eastern Adriatic recorded in speleothems from Mala špilja Cave and Velika špilja Cave (Mljet Island, Croatia), Acta Carsologica, 46, 229-249, 2017.

Macklin, M. G., Toonen, W. H. J., Woodward, J. C., Williams, M. A. J., Flaux, C., Marriner, N., Nicoll, K., Verstraeten, G., Spencer, N., and Welsby, D.: A new model of river dynamics, hydroclimatic change and human settlement in the Nile Valley derived from meta-analysis of the Holocene fluvial archive, Quaternary Sci. Rev., 130, 109-123, 2015.

Manning, J. G.: The open sea, the economy and life of the ancient Mediterranean world from the Iron Age to the rise of Rome, Princeton University Press, Princeton and Oxford, 2018.

Magny, M., Vannière, B., Zanchetta, G., Fouache, E., Touchais, G., Petrika, L., Coussot, C., Walter-Simonnet, A. V., and Arnaud, F.: Possible complexity of the climatic event around 4300-3800 cal. BP in the central and western Mediterranean, Holocene, 19, 823-833, 2009.

Magny, M., Combourieu-Nebout, N., de Beaulieu, J. L., BoutRoumazeilles, V., Colombaroli, D., Desprat, S., Francke, A., Joannin, S., Ortu, E., Peyron, O., Revel, M., Sadori, L., Siani, G., Sicre, M. A., Samartin, S., Simonneau, A., Tinner, W., Vannière, B., Wagner, B., Zanchetta, G., Anselmetti, F., Brugiapaglia, E., Chapron, E., Debret, M., Desmet, M., Didier, J., Essallami, L., Galop, D., Gilli, A., Haas, J. N., Kallel, N., Millet, L., Stock, A., Turon, J. L., and Wirth, S.: North-south palaeohydrological contrasts in the central Mediterranean during the Holocene: tentative synthesis and working hypotheses, Clim. Past, 9, 20432071, https://doi.org/10.5194/cp-9-2043-2013, 2013.

Marks, L., Salem, A., Welc, F., Nitychoruk, J., Chen, Z., Blaauw, M., Zalat, A., Majecka, A., Szymanek, M., Chodyka, M., Tołoczko-Pasek, A., Sun, Q., Zhao, X., and Jiang, J.: Holocene lake sediments from the Faiyum Oasis in Egypt: a record of environmental and climate change, Boreas, 47, 62-79, 2018.

Marriner, N., Flaux, C., Kaniewski, D., Morhange, C., Leduc, G., Moron, V., Chen, Z., Gasse, F., Empereur, J. Y., and Stanley, J. D.: ITCZ and ENSO-like modulation of Nile delta hydrogeomorphology during the Holocene, Quaternary Sci. Rev., 45, 73-84, 2012.

Marriner, N., Flaux, C., Morhange, C., and Stanley, J. D.: Tracking Nile Delta vulnerability to Holocene change, Plos One, 8, 7, e69195, https://doi.org/10.1371/journal.pone.0069195, 2013.

Marshall, M., Lamb, H. F., Huws, D., Davies, S. J., Bates, R., Bloemendal, J., Boyle, J., Leng, M. J., Umer, M., and Bryant, C.: Late Pleistocene and Holocene drought events at Lake Tana, the source of the Blue Nile, Global Planet. Change, 78, 147-161, 2011.

Mayewski, P. A., Rohling, E. J., Stager, J. C., Karlén, W., Maasch, K. A., Meeker, L. D., Meyerson, E. A., Gasse, F., Van Kreveld, S., Holmgren, K., Lee-Thorp, K., Rosqvist, G., Rack, F., Staub- wasser, M., Schneider, R. R., and Steig, E. J.: Holocene Climate Variability, Quaternary Res., 62, 243-255, 2004.

Meadows, J.: The Younger Dryas episode and the radiocarbon chronologies of the Lake Huleh and Ghab Valley pollen diagrams, Israel and Syria, Holocene, 15, 631-636, 2005.

Miebach, A., Chen, C. Z., Schwab, M. J., Stein, M., and Litt, T.: Vegetation and climate during the Last Glacial high stand (ca. 28-22 ka bp) of the Sea of Galilee, northern Israel, Quaternary Sci. Rev., 156, 47-56, 2017.

Migowski, C., Stin, M., Prasad, S., Negendank, J. F. W., and Agnon, A.: Holocene climate variability and cultural evolution in the Near East from the Dead Sea sedimentary record, Quaternary Res., 66, 421-431, 2006.

Moy, C. M., Seltzer, G. O., Rodbell, D. T., and Anderson, D. M.: Variability of El Niño southern oscillation activity at millennial timescales during the Holocene epoch, Nature, 420, 162-165, 2002.

Neumann, F., Schölzel, C., Litt, T., Hense, A., and Stein, M.: Holocene vegetation history and climate history of the north Golan Heights (Near East), Veg. Hist. Archaeobot., 16, 329-46, 2007a.

Neumann, F. H., Kagan, E. J., Schwab, M. J., and Stein, M.: Palynology, sedimentology and palaeoecology of the late Holocene Dead Sea, Quaternary Sci. Rev., 26, 1476-1498, 2007 b.

Nicholson, S. E. and Selato, J. C.: The influence of La Nina on African rainfall, Int. J. Climatol., 20, 1761-1776, 2000.

Olsen, J., Anderson, N. J., and Knudsen, M. F.: Variability of the North Atlantic Oscillation over the past 5,200 years, Nat. Geosci., 5, 808-812, https://doi.org/10.1038/ngeo1589, 2012.

Regattieri, E., Zanchetta, G., Drysdale, R. N., Isola, I., Hellstrom, J. C., and Dallai, L.: Lateglacial to Holocene trace element record (Ba, Mg, Sr) from Corchia Cave (Apuan Alps, central Italy): paleoenvironmental implications, J. Quaternary Sci., 29, 381-392, 2014.

Revel, M., Ducassou, E., Grousset, F. E., Bernasconi, S. M., Migeon, S., Revillon, S., Mascle, J., Murat, A., Zaragosi, S., and Bosch, D.: 100,000 years of African monsoon variability recorded in sediments of the Nile next term margin, Quaternary Sci. Rev., 29, 1342-1362, 2010.

Roberts, N., Jones, M. D., Benkaddour, A., Eastwood, W. J., Filippi, M. L., Frogley, M. R., Lamb, H. F., Leng, M. J., Reed, J. M., Stein, M., Stevens, L., Valero-Garces, B., and Zanchetta, G.: Stable isotope records of Late Quaternary climate and hydrology from Mediterranean lakes: the ISOMED synthesis, Quaternary Sci. Rev., 27, 2426-2441, 2008.

Roberts, N., Moreno, A., Valero-Garces, B. L., Corella, J. P., Jones, M., Allcock, S., Woodbridge, J., Morellon, M., Luterbacher, J., Xoplaki, E., and Turkes, M.: Palaeolimnological evidence for an east-west climate see-saw in the Mediterranean since AD 900, Global Planet. Change, 84-85, 23-34, 2012.

Rohling, E. J., Mayewski, P. A., Abu-Zied, R. H., Caford, J. S. L., and Hayes, A.: Holocene atmosphere-ocean interactions: records from Greenland and the Aegean Sea, Clim. Dynam., 18, 587593, 2002.

Rossignol-Strick, M.: African monsoons, an immediate climate response to orbital insolation, Nature, 304, 46-49, 1983.

Rossignol-Strick, M.: Sea-land correlation of pollen records in the Eastern Mediterranean for the glacial-interglacial transition: 
biostratigraphy versus radiometric time-scale, Quaternary Sci. Rev., 14, 8930-915, 1995.

Rothacker, L., Dosseto, A., Francke, A., Chivas, A., Vigier, N., Kotarba-Morley, A. M., and Menozzi, D.: Impact of climate change and human activity on soil landscapes over the past 12,300 years, Sci. Rep., 8, 1-7, https://doi.org/10.1038/s41598017-18603-4, 2018.

Ruan, J., Kherbouche, F., Genty, D., Blamart, D., Cheng, H., Dewilde, F., Hachi, S., Edwards, R. L., Régnier, E., and Michelot, J.-L.: Evidence of a prolonged drought ca. $4200 \mathrm{yr}$ BP correlated with prehistoric settlement abandonment from the Gueldaman GLD1 Cave, Northern Algeria, Clim. Past, 12, 1-14, https://doi.org/10.5194/cp-12-1-2016, 2016.

Saaroni, H., Halfon, N., Ziv, B., Alpert, P., and Kutiel, H.: Links between the rainfall regime in Israel and location and intensity of Cyprus lows, Int. J. Climatol., 30, 1014-1025, 2010.

Schiebel V. and Litt, T.: Holocene vegetation history of the southern Levant based on a pollen record from Lake Kinneret (Sea of Galilee), Israel, Veg. Hist. Archaeobot., 27, 577-590, 2018.

Schilman, B., Bar-Matthews, M., Almogi-Labin, A., and Luz, B.: Global climate instability reflected by Eastern Mediterranean marine records during the Late Holocene, Palaeogeogr. Palaeocl., 176, 157-176, 2001.

Schmidt, R., Müller, J., Drescher-Schneider, R., Krisai, R., Szeroczyńska, K., and Barić, A.: Changes in lake level and trophy at Lake Vrana, a large karstic lake on the Island of Cres (Croatia), with respect to palaeoclimate and anthropogenic impacts during the last approx. 16,000 years, J. Limnol., 59, 113-130, 2000.

Schwab, M. J., Neumann, F., Litt, T., Negendank, J. F. W., and Stein, M.: Holocene palaeoecology of the Golan Heights (Near East): investigation of lacustrine sediments from Birkat Ram crater lake, Quaternary Sci. Rev., 23, 1723-1731, 2004.

Scussolini, P., Vegas-Vilarrúbia, T., Rull, V., Corella J. P., ValeroGarcés, B., and Gomà, J.: Middle and late Holocene climate change and human impact inferred from diatoms, algae and aquatic macrophyte pollen in sediments from Lake Montcortès (NE Iberian Peninsula), J. Paleolimnol., 46, 369-385, 2011.

Sharifi, A., Pourmand, A., Canuel, E. A., Ferer-Tyler, E., Peterson, L. C., Aichner, B., Feakins, S. J., Daryaee, T., Djamali, M., Naderi, A., Lahijani, H. A. K., and Swart, P. K.: Abrupt climate variability since the last deglaciation based on a high-resolution, multi-proxy peat record from NW Iran: the hand that rocked the Cradle of Civilization?, Quaternary Sci. Rev., 123, 215-230, 2015

Solomina, O. N., Bradley, R. S., Hodgson, D. A., Ivy-Ochs, S., Jomelli, V., Mackintosh, A. N., Nesje, A., Owen, L. A., Wanner, H., Wiles, G. C., and Young, N. E.: Holocene glacier fluctuations, Quaternary Sci. Rev., 111, 9-34, 2015.

Sorrel, P. and Mathis, M.: Mid- to late Holocene coastal vegetation patterns in Northern Levant (Tell Sukas, coastal Syria): Olive tree cultivation history and climatic change, Holocene, 26, 858-873, 2016.

Stanley, J. D., Krom, M. D., Cliff, R. A., and Woodward J. C.: Short Contribution: Nile flow failure at the end of the Old Kingdom, Egypt: strontium isotopic and petrologic evidence, Geoarchaeology, 18, 395-402, 2003.

Staubwasser, M. and Weiss, H.: Holocene climate and cultural evolution in late prehistoric-early historic West Asia, Quaternary Res., 66, 372-387, 2006.
Styllas, M., Dimitriou, E., Gritzalis, K., Koutsodimou, M., Karaouzas, I., Skoulikidis, N., and Gogou, A.: MidHolocene changes in the geochemical and biotic conditions of an aquatic ecosystem, in Eastern Mediterranean. Annales de Limnologie-International J. Limnol., 54, 1-15, https://doi.org/10.1051/limn/2018013, 2018.

Telford, R. J., Heegaard, E., and Birks, H. J. B.: The intercept is a poor estimate of a calibrated radiocarbon age, Holocene, 14, 296-298, 2004.

Thienemann, M., Masi, A., Kusch, S., Sadori, L., John, S., Francke, A., Wagner, B., and Rethemeyer, J.: Organic geochemical and palynological evidence for Holocene natural and anthropogenic environmental change at Lake Dojran (Macedonia/Greece), Holocene, 27, 1103-1114, 2017.

Thompson, L. G., Mosley-Thompson, E., Davis, M. E., Henderson, K. A., Brecher, H. H., Zagorodnov, V. S., Mashiotta, T. A., and Lin, P. N.: Kilimanjaro ice core records: evidence of Holocene climate change in tropical Africa, Science, 298, 589-593, 2002.

van Zeist, W. and Woldring, H.: Holocene vegetation and climate of northwestern Syria, Palaeohistoria, 22, 111-125, 1980.

Van Zeist, W., Baruch, U., and Bottema, S.: Holocene palaeoecology of the Hula area, northeastern Israel, in: A timeless vale, Archaeological Studies Leiden University 19, edited by: Kaptijn, E. and Petit, L. P., Leiden University Press, Leiden, 29-64, 2009.

Verheyden, S., Nader, F. H., Cheng, H. J., Edwards, L. R., and Swennen, R.: Paleoclimate reconstruction in the Levant region from the geochemistry of a Holocene stalagmite from the Jeita cave, Lebanon, Quaternary Res., 70, 368-381, 2008.

Véron, A., Flaux, C., Marriner, N., Poirier, A., Rigaud, S., Morhange, C., and Empereur, J. Y.: A 6000-year geochemical record of human activities from Alexandria (Egypt), Quaternary Sci. Rev., 81, 138-147, 2013.

Verschuren, D., Sinninghe Damsté, J. S., Moernaut, J., Kristen, I., Blaauw, M., Fagot, M., Haug, G. H., and Challacea Project Members: Half-precessional dynamics of monsoon rainfall near the East African Equator, Nature, 462, 637-641, 2009.

Wagner, B., Vogel, H., Zanchetta, G., and Sulpizio, R.: Environmental change within the Balkan region during the past ca. $50 \mathrm{ka}$ recorded in the sediments from lakes Prespa and Ohrid, Biogeosciences, 7, 3187-3198, https://doi.org/10.5194/bg-7-31872010, 2010.

Walker, M. J. C., Berkelhammer, M., Björck, S., Cwynar, L. C., Fisher, D. A., Long, A. J., Lowe, J. J., Newnham, R. M., Rasmussen, S. O., and Weiss, H.: Formal subdivision of the Holocene Series/Epoch: A discussion paper by a Working Group of INTIMATE (Integration of ice-core, marine and terrestrial records) and the subcommission on quaternary stratigraphy (International Commission on Stratigraphy), J. Quaternary Sci., 27, 649-659, 2012.

Wanner, H., Beer, J., Bütikofer, J., Crowley, T. J., Cubasch, U., Flükiger, J., Goosse, H., Grosjean, M., Joos, F., Kaplan, J. O., Küttel, M., Müller, S. A., Prentice, I. C., Solomina, O., Stocker, T. F., Tarasov, P., Wagner, M., and Widmann, M.: Mid- to Late Holocene climate change: an overview, Quaternary Sci. Rev., 27, 1791-1828, 2008.

Wanner, H., Solomina, O., Grosjean, M., Ritz, S. P., and Jetel, M.: Structure and origin of Holocene cold events, Quaternary Sci. Rev., 30, 3109-3123, 2011. 
Wanner, H., Mercolli, L., Grosjean, M., and Ritz, S.: Holocene climate variability and change; a data-based review, J. Geol. Soc., 172, 254-263, 2015.

Weiss, H.: Global megadrought, societal collapse and resilience at 4.2-3.9 ka BP across the Mediterranean and west Asia, PAGES, 24, 62-63, https://doi.org/10.22498/pages.24.2.62, 2016.

Weiss, H.: Megadrought and collapse, from early agriculture to Angkor, Ox

Weiss, H. and Bradley, R. S.: What drives societal collapse?, Science, 291, 609-610, 2001. ford University Press, Oxford, 2017.

Weiss, H., Courty, M. A.,Wetterstrom, W., Guichard, F., Senior, L., Meadow, R., and Curnow, A.: The genesis and collapse of 3rd millennium north Mesopotamian civilization, Science, 261, 9951004, 1993.

Wick, L., Lemcke, G., and Sturm, M.: Evidence of Lateglacial and Holocene climatic change and human impact in eastern Anatolia: high-resolution pollen, charcoal, isotopic and geochemical records from the laminated sediments of Lake Van, Turkey, Holocene, 13, 665-675, 2003.

Wolff, C., Haug, G. H., Timmermann, A., Sinninghe Damsté, J. S., Brauer, A., Sigman, D. M., Cane, M. A., and Verschuren, D.: Reduced interannual rainfall variability in East Africa during the last ice age, Science, 333, 743-747, 2011.

Xoplaki, E., Gonzalez-Rouco, J. F., Luterbacher, J., and Wanner, H.: Wet season Mediterranean precipitation variability: influence of large-scale dynamics and trends, Clim. Dynam., 23, 63-78, https://doi.org/10.1007/s00382-004-0422-0, 2004.
Yasuda, Y., Kitagawa, H., and Nakagawa, T.: The earliest record of major anthropogenic deforestation in the Ghab Valley, northwest Syria: a palynological study, Quatern. Int., 73/74, 127-136, 2000.

Zanchetta, G., Van Welden, A., Baneschi, I., Drysdale, R. N., Sadori, L., Roberts, N., Giardini, M., Beck, C., Pascucci, V., and Sulpizio, R.: Multiproxy record for the last 4500 years from Lake Shkodra (Albania/Montenegro), J. Quaternary Sci. 27, 780-789, 2012.

Zanchetta, G., Regattier, E., Isola, I., Drysdale, R. N., Bini, M., Baneschi, I., and Hellstrom, J. C.: The so-called "4.2 event" in the central Mediterranean and its climatic teleconnections, Alpine and Mediterranean Quaternary, 29, 5-17, 2016.

Zanchetta, G., Bini, M., Di Vito, M. A., Sulpizio, R., and Sadori, L.: Tephrostratigraphy of paleoclimatic archives in central Mediterranean during the Bronze Age, Quatern. Int., in press, https://doi.org/10.1016/j.quaint.2018.06.012, 2018.

Zangvil, A., Karas, S., and Sasson, A.: Connection between eastern Mediterranean seasonal mean $500 \mathrm{hPa}$ height and sea-level pressure patterns and the spatial rainfall distribution over Israel, Int. J. Climatol., 23, 1567-1576, 2003.

Zielhofer, C. and Faust, D.: Mid- and Late Holocene fluvial chronology of Tunisia, Quaternary Sci. Rev., 27, 580-588, 2008.

Ziv, B., Dayan, U., Kushnir, Y., Roth, C., and Enzel, Y.: Regional and global atmospheric patterns governing rainfall in the southern Levant, Int. J. Climatol. 26, 55-73, 2006. 